\title{
Sinus venous thrombosis as a complication of COVID-19-associated hypercoagulability
}

\author{
Sinda Zarrouk ${ }^{1}$ and Josef Finsterer ${ }^{2^{*}}$ (1)
}

\begin{abstract}
Sinus venous thrombosis (SVT) is an increasingly recognised complication of not only SARS-CoV-2 infections, but also of SARS-CoV-2 vaccinations. SVT is attributed to hypercoagulability, a common complication of COVID-19, disregarding the severity of the infection. Hypercoagulability in COVID-19 is explained by direct activation of platelets, enhancing coagulation, by direct infection and indirect activation of endothelial cells by SARS-CoV-2, shifting endothelial cells from an anti-thrombotic to a pro-thrombotic state, by direct activation of complement pathways, promoting thrombin generation, or by immune thrombocytopenia, which also generates a thrombogenic state. Since SVT may occur even in anticoagulated COVID-19 patients and may have an unfavourable outcome, all efforts must be made to prevent this complication or to treat it accurately.
\end{abstract}

Keywords: SARS-CoV-2, COVID-19, Hypercoagulability, Thrombosis, Complications

\section{Introduction}

With interest we read the article by Sittanggang and colleagues about two patients (58-year-old female (patient-1), 72-year-old male (patient-2)) experiencing sinus venous thrombosis (SVT) during a SARS-CoV-2 infection [1]. Latency between the onset of COVID-19 and the onset of SVT was 7 and 17 days in patient-1/ patient-2, respectively [1]. The onset manifestations were seizure and hemiparesis (patient-1) and impaired consciousness (patient-2), respectively [1]. It was concluded that COVID-19 can be complicated by SVT, that the prognosis of SVT is poor if drainage of the brainstem is compromised, that hypercoagulability is a complication of COVID-19 if arterial hypertension and diabetes are present, and that coagulation cascades are prolonged despite normal D-dimer [1]. The study is appealing, but raises comments and concerns.

\begin{abstract}
Main text
We do not agree with the statement that hypercoagulability is a complication of COVID-19 only if there is concomitant arterial hypertension or diabetes [1]. Hypercoagulability is a common complication not only of severe, but also of mild or moderate COVID-19 [2] and explained by (1) direct activation of platelets, enhancing coagulation; (2) direct infection and indirect activation of endothelial cells by the cytokine storm, shifting endothelium from an anti-thrombotic to a pro-thrombotic state, and (3) direct activation of complement pathways, promoting thrombin generation [3]. Since SARS-CoV-2 activates the immune system, autoimmune disease is a frequent complication [4], including immune thrombocytopenia, which may further enhance the thrombogenic state in COVID-19 patients [5]. There are also indications for alterations of the clotting factor titers and activation of platelets, which leads to thrombus formation in coronary arteries and cerebral arteries [6].
\end{abstract}

*Correspondence: fifigs1@yahoo.de

2 Klinik Landstrasse, Messerli Institute, Postfach 20, 1180 Vienna, Austria

Full list of author information is available at the end of the article original author(s) and the source, provide a link to the Creative Commons licence, and indicate if changes were made. The images or other third party material in this article are included in the article's Creative Commons licence, unless indicated otherwise in a credit line to the material. If material is not included in the article's Creative Commons licence and your intended use is not permitted by statutory regulation or exceeds the permitted use, you will need to obtain permission directly from the copyright holder. To view a copy of this licence, visit http://creativecommons.org/licenses/by/4.0/. 
A limitation of the study is that only computed tomography $(\mathrm{CT})$ scans of the brain were provided. Since SVT is frequently complicated by ischaemic stroke with or without consecutive bleeding [7], and since ischaemic stroke, particularly small ones, are only detectable on multimodal magnetic resonance imaging (MRI) [8], it is worthwhile to know if multimodal MRIs of the brain are available and if ischaemic stroke was documented on MRI in either patient. Since SVT may be associated also with bleeding, we should know if cerebral CT scans demonstrated intracerebral bleeding in either patient.

The statement of the conclusions "upon monitoring the neutrophil/lymphocyte ratio, it became apparent that D-dimer, fibrinogen, and $\mathrm{C}$-reactive protein (CRP) are bad prognosis indicators, why the use of heparin or low molecular weight heparin (LMWH) decreases the D-dimer and not by any means increase the symptoms" [1] is inconclusive. Do the authors mean that LMWH decreases the D-dimer levels but not the symptoms, or do they mean that low D-dimer is associated with reduction of symptoms? This should be clarified. Recently, it has been proposed to apply standardised viscoelastic tests, such as TEG, Quantra, ROTEM, or ClotPro, to assess haemostasis and the thrombotic risk in COVID-19 patients [9].

Patient-1 was described as having arterial hypertension as the only peculiarity in her previous history. However, according to table 1 in the article by Sittanggang and colleagues the HbA1c value was 6.5 , suggesting that the patient was also diabetic. We should know if diabetes was first diagnosed during hospitalisation or previously known.

Missing is the drug history. We should be told if either patient was regularly taking hormones. Missing is an extensive history for other risk factors for SVT, such as smoking, antiphospholipid syndrome, thrombophilia (elevated protein-S or protein-C), or inflammatory bowel disease [10].

Table 1 of the article by Sittnaggang and colleagues does not provide reference limits of any parameter listed. This is why it cannot be assessed which of the listed figures of table 1 are normal or abnormal. It is also unclear what is meant with "INR 5.308 (before 50,000) (patient-2)" It should be mentioned if hemiparesis in patient-1 was right-sided or left-sided.

\section{Conclusions}

The presented study has limitations, which weaken the findings and their interpretation. These limitations should be addressed to further strengthen the conclusions.
Abbreviations

CRP: C-reactive protein; CT: Computed tomography; LMWH: Low molecular weight heparin; MRI: Magnetic resonance imaging; SVT: Sinus venous thrombosis.

\section{Acknowledgements \\ Not applicable}

\section{Authors' contributions}

SZ: literature search, discussion, critical comments, final approval. JF: design, literature search, discussion, first draft, critical comments, final approval. All authors have read and approved the manuscript, and ensure that this is the case. Both authors read and approved the final manuscript.

Funding

None received.

Availability of data and materials

All data are available from the corresponding author.

\section{Declarations}

Ethics approval and consent to participate

Not applicable.

Consent for publication

Not applicable.

Competing interests

The authors declare that they have no competing interests.

\section{Author details}

${ }^{1}$ University of Tunis El Manar and Genomics Platform, Pasteur Institute of Tunis, Tunis, Tunisia. ${ }^{2}$ Klinik Landstrasse, Messerli Institute, Postfach 20, 1180 Vienna, Austria.

Received: 26 July 2021 Accepted: 8 September 2021

Published online: 26 September 2021

\section{References}

1. Sitanggang PA, Tini K, Susilawathi NM, Wijayanti IAS, Dewi PU, Samatra DPGP. Case reports of cerebral sinus venous thrombosis in COVID-19 patients. Egypt J Neurol Psychiatr Neurosurg. 2021;57(1):83. https://doi. org/10.1186/s41983-021-00335-y.

2. Sandor-Keri J, Benedek I, Polexa S, Benedek I. The link between SARS-CoV-2 infection, inflammation and hypercoagulability-impact of hemorheologic alterations on cardiovascular mortality. J Clin Med. 2021;10(14):3015. https://doi.org/10.3390/jcm10143015.

3. Steadman E, Fandaros M, Yin W. SARS-CoV-2 and plasma hypercoagulability. Cell Mol Bioeng. 2021;28:1-10. https://doi.org/10.1007/ s12195-021-00685-w.

4. Finsterer J, Scorza FA. Guillain-Barre syndrome in 220 patients with COVID-19. Egypt J Neurol Psychiatr Neurosurg. 2021;57(1):55. https://doi. org/10.1186/s41983-021-00310-7.

5. Wiedmann M, Skattør T, Stray-Pedersen A, Romundstad L, Antal EA, Marthinsen PB, Sørvoll IH, Leiknes Ernstsen S, Lund CG, Holme PA, Johansen TO, Brunborg C, Aamodt AH, Schultz NH, Skagen K, Skjelland M. Vaccine induced immune thrombotic thrombocytopenia causing a severe form of cerebral venous thrombosis with high fatality rate: a case series. Front Neurol. 2021;30(12): 721146. https://doi.org/10.3389/fneur.2021.721146.

6. Nuthalapati P, Ghanta MK, Natesh NS, Bhaskar LV. Association of hypercoagulation with severe acute respiratory syndrome coronavirus 2 infection. Blood Res. 2021;56(2):61-4. https://doi.org/10.5045/br.2021.2021011.

7. Ferro JM, Canhão P. Cerebral venous sinus thrombosis: update on diagnosis and management. Curr Cardiol Rep. 2014;16(9):523. https://doi.org/10. 1007/s11886-014-0523-2. 
8. Moreau F, Asdaghi N, Modi J, Goyal M, Coutts SB. Magnetic resonance imaging versus computed tomography in transient ischemic attack and minor stroke: the more you see the more you know. Cerebrovasc Dis Extra. 2013;3(1):130-6. https://doi.org/10.1159/000355024.

9. Bareille M, Hardy M, Douxfils J, Roullet S, Lasne D, Levy JH, Stépanian A, Susen S, Frère C, Lecompte T, Mullier F. Viscoelastometric testing to assess hemostasis of COVID-19: a systematic review. J Clin Med. 2021;10(8):1740. https://doi.org/10.3390/jcm10081740.

10. Bano S, Farooq MU, Nazir S, Aslam A, Tariq A, Javed MA, Rehman H, Numan A. Structural imaging characteristic, clinical features and risk factors of cerebral venous sinus thrombosis: a prospective cross-sectional analysis from a tertiary care hospital in Pakistan. Diagnostics (Basel). 2021;11(6):958. https://doi.org/10.3390/diagnostics11060958.

\section{Publisher's Note}

Springer Nature remains neutral with regard to jurisdictional claims in published maps and institutional affiliations.

\section{Submit your manuscript to a SpringerOpen ${ }^{\circ}$ journal and benefit from:}

- Convenient online submission

- Rigorous peer review

- Open access: articles freely available online

- High visibility within the field

- Retaining the copyright to your article

Submit your next manuscript at $\boldsymbol{\nabla}$ springeropen.com 